\title{
UPAYA PEMULIHAN PARIWISATA BUDAYA PASCA KONFLIK ETNIS DI KECAMATAN SAMBAS KABUPATEN SAMBAS
}

\author{
Hikmah Trisnawati \\ Manajemen Bisnis Pariwisata, Politeknik Negeri Sambas \\ email: hikmah.trisnawati@gmail.com \\ Nurchalis \\ Manajemen Bisnis Pariwisata, Politeknik Negeri Sambas \\ email: alwaysolys@yahoo.co.id
}

\begin{abstract}
This research aims to study get the real understanding about efforts the recovery of cultural tourism after ethnic conflict Madura-Malayu in Sambas District Sambas Regency. Then, to see the problem development cultural tourism and effort of stakeholder to develop tourism in Sambas District. This research used qualitative method. Result of this research are stakeholder have the effort to develop the cultural tourism such as increase the infrastructure, increases human resources management, keep the safety of this regions and gave the promotion of cultural tourism. They have the difficulties of increase the development likes need more integrity of stakehoder beside this; they haven't good relationship with the Madura Ethnic although many people tried well come to all the ethnic for come to Sambas District.
\end{abstract}

Key word:

conflict ethnic, cultural tourism, recovery. 


\section{PENDAHULUAN}

Pariwisata juga dapat menjadi cara untuk membuka keterisolasian geografis dan sosial melalui bentuk-bentuk sosial dan budaya antara penduduk lokal atau warga masyarakat dengan para wisatawan yang mengunjungi daerah tersebut. Pertemuan antara host dan guest dipandang dapat memberikan dampak positif bagi warga masyarakat dalam berbagai aspek.

Terdapat tiga kekuatan yang dapat membuka keterisolasian suatu masyarakat yang sebelum tersentuh oleh budaya luar melalui pariwisata, yaitu pendidikan, perkembangan industri dan kontak budaya. Kekuatan tersebut dapat diuraikan secara rinci sebagai berikut: Pendidikan merupakan salah satu proses sosialisasi dalam rangka mempersiapkan anggota mayarakat untuk dapat menerima ide atau gagasan dan teknologi baru dari perubahanperubahan seperti aparat pemerintah, para pedagang, guru, pemuka agama dan lain-lain. Perkembangan industri juga merupakan unsur kekuatan pendorong keterbukaan masyarakat hingga ada lembaga yang bersifat ekonomis melalui pasar yang ada. Sedangkan pasar itu sendiri merupakan tempat pertemuan masyarakat, tidak hanya untuk menjual produkproduk yang dihasilkan oleh masyarakat tersebut tetapi, juga sebagai tempat interaksi sosial yang lebih luas. Kontak budaya merupakan kekuatan pendorong yang tidak kalah pentingnya dalam membuka keterisolasian suatu masyarakat.

Sebagaimana telah dijelaskan di atas bahwa pariwisata merupakan salah satu sektor penting bagi sumber pendapatan daerah termasuk Kabupaten Sambas di Kalimantan Barat. Mengingat pentingnya pariwisata sehingga tiap daerah di Indonesia berupaya untuk melakukan pengembangan sektor pariwisata masing-masing tidak terkecuali daerah Sambas. Sambas juga memiliki potensi wisata budaya yang menarik. Kabupaten Sambas merupakan salah satu Kabupaten yang terletak di daerah pesisir utara Pulau Kalimantan tepatnya di
Provinsi Kalimantan Barat. Secara historis Sambas merupakan sebuah kerajaan yang terkenal akan kejayaan masa lalunya dan berperadaban maju, sehingga sejak dulu hingga sekarang Sambas selalu didatangi orang untuk belajar dan berdagang. Bahkan Sambas pernah memiliki Imam Fiqih yang sangat terkenal baik di Indonesia maupun Timur Tengah yaitu Syech Ahmad Khotib.

Dari dahulu sektor pariwisata mulai terbangun di Kabupaten Sambas. Akan tetapi sejak terjadinya konflik etnis yang terjadi tahun 1999 sektor pariwisata mengalami kemunduran dan kurang diperhatikan. Terjadinya peristiwa konflik etnis di Kabupaten Sambas tahun 1999, dikenal sebagai "Tragedi Lebaran Berdarah" (Musa dan Johansen, 2000). Peristiwa ini merupakan sebuah tragedi sosial antar etnis yang selama ini hidup berdampingan. Sebagai bentuk sejarah maka peristiwa ini diabadikan dengan pembuatan Tugu Ketupat Berdarah di Kecamatan Jawai Kabupaten Sambas Provinsi Kalimantan Barat.

Melalui latar belakang konflik ini maka diharapkan muncul destinasi-destinasi pariwisata baru di Sambas. Selain itu dapat membuka interaksi yang baik antar masyarakat yang bertikai selama ini, yang hingga saat ini salah satu etnis tertentu belum boleh tinggal di Kabupaten Sambas. Sehingga pada akhirnya pariwisata hadir sebagai sarana untuk mewujudkan perdamaian sejati.

Pada dasarnya masyarakat melayu memiliki potensi yang baik untuk mengembangkan pariwisata. Sambas memiliki perairan sungai yang sangat indah dan selalu menjadi ajang menarik baik bagi masyarakat lokal maupun Internasional. Sedangkan mengenai orang Sambas itu sendiri menurut Duarte Barbosa (dalam Asmara, 2001) mengatakan tentang orang Melayu Sambas "mereka itu bersih dan berketurunan baik, sangat gemar akan musik, dan sangat berkasih sayang". Vallentin (dalam Asmara, 2001) menyatakan juga menggambarkan etnis Melayu Sambas "mereka

\section{\begin{tabular}{l|l} 
JNP & 56
\end{tabular}}


terbuka kepada siapa saja yang datang. Hal ini tercermin dalam peribahasa kecil telapak tangan, nyiru kami tadahkan". Sifat utama orang Melayu sebagai pencerminan budayanya adalah sabar, pemaaf dan sangat menghormati tamu. Berbekal kepribadian seperti ini sebenarnya Sambas mampu mengemas dan mengembangkan pariwisatanya lebih baik. Selanjutnya penelitian ini dilakukan untuk mengungkap perkembangan pariwisata budaya khususnya di Kecamatan Sambas pasca konflik etnis tahun 1999.

\section{KAJIAN LITERATUR}

Dalam rangka mempertahankan bahkan mengembangkan kepariwisataan lebih lanjut di Kabupaten Sambas. Menurut (Ardika, 2002) dalam tulisanya "upaya pemulihan bom Bali" kiranya bisa menjadi acuan untuk mengkaji konflik yang ada di Kabupaten Sambas. Hal yang perlu di tingkatkan yakni communitybase suistainable Tourism Development melalui langkah awal berupa revitalisasi potensi khas lokal (local genius). Disamping itu diperlukan strategi peningkatan keamanan melalui (a) tertib administrasi kependudukan dan pengawasan terhadap mobilisasi penduduk pendatang, (b) pemberdayaan semua komponen masyarakat, baik secara langsung maupun tidak langsung bertanggung jawab atas keamanan secara bersama-sama untuk menciptakan rasa aman terhadap masyarakat setempat (host) dan wisatawan.

Selain itu penelitian dari (Nurchalis, 2011: 132-133) sebelumnya juga menjadi referensi pada tulisan ini yakni mengenai cagar budaya keraton sambas dinyatakan bahwa potensi mendasar yang menjadi sumber daya budaya dari Keraton Alwatzikhoebillah Sambas sebagai destinasi wisata sejarah sekaligus menjadi daya tarik wisata adalah nilai sejarah dan sosial budaya yang terkandung baik secara implisit maupun ekspklisit. Secara implisit potensi sumber daya budaya berupa nilai-nilai sejarah dan perjuangan masyarakat, lambang sejarah masuk dan perkembangan reformisme agama Islam serta lambang perkembangan dan pembangunan sosial budaya masyarakat Sambas, sedangkan secara eksplisit potensi sumber daya budaya yang paling menonjol selain keraton merupakan lambang warisan budaya masyarakat melayu Sambas dan benda cagar budaya ia juga implementasi nilai sakral/ mistis/spiritual masyarakat Sambas. Semuanya merupakan nilai-nilai sosial budaya yang sangat penting dari Keraton Alwatzikhoebillah Sambas sebagai warisan budaya masyarakat melayu Sambas yang harus dijaga dan dipelihara demi untuk kepentingan masa sekarang maupun akan datang.

Berdasarkan potensi sumber daya budaya potensial yang ada menyebabkan Keraton Alwatzikhoebillah Sambas menjadi destinasi wisata yang mempunyai daya tarik khususnya sejarah dan mendorong banyak wisatawan berkunjung baik yang datang dari dalam maupun luar Sambas. Faktor-faktor yang mendorong wisatawan datang mengunjungi Keraton Alwatzikhoebillah Sambas baik intrinsik maupun ekstrinsik didorong oleh motif untuk refreshing/liburan, motif pendidikan, motif ingin tahu dan memperluas wawasan, motif sosial/motif interpersonal, motif budaya dan motif spiritual/religius.

Teori merupakan alat terpenting dalam suatu penelitian ilmiah sebagai alat dalam mengkaji Pemulihan Pariwisata Budaya Pasca Konflik Etnis Melayu-Madura Kabupaten Sambas. Teori yang dapat digunakan dalam penelitian ini yaitu: Teori Fungsional Struktural digunakan untuk menganalisa interaksi Pemerintah Kabupaten Sambas, stakeholder dan masyarakat. Kemudian teori Interaksi Simbolik untuk memberikan pemahaman makna dalam pemulihan pariwisata tersebut.

\section{METODE PENELITIAN}

Penelitian ini menggunakan metode kualitatif, yaitu metode yang merupakan strategi 
untuk mendapatkan data atau keterangan seperti yang disampaikan Bogdan dan Tylor, metode kualitatif diartikan sebagai prosedur penelitian yang menghasilkan data deskriptif berupa kata-kata tertulis atau lisan dari orang-orang dan perilaku yang dapat diamati (Moleong, 2010). Kemudian lokasi penelitian ini adalah Kecamatan Sambas berangkat dari ketertarikan peneliti pada pemulihan pariwisata yang dilatarbelakangi oleh peristiwa konflik yang terjadi di Kabupaten Sambas tahun 1999, dan pengetahuan peneliti dari masyarakat setempat, dilakukan observasi dan penelitian singkat mulai dilakukan di Sambas. Hal ini dilakukan, karena peneliti memiliki kemudahan aksesibilitas untuk memperoleh gambaran awal mengenai lokasi pariwisata dan latar belakang persoalan Konflik Sambas tersebut. Berawal dari observasi singkat tersebut dan diputuskan untuk melakukan penelitian ini. Sambas merupakan wilayah yang multi etnik, dan juga memiliki objek wisata yang cukup menarik, baik itu wisata alam, wisata budaya, maupun wisata sejarah. Daerah ini juga merupakan dataran rendah atau daerah pesisir yang banyak dialiri sungai. Sebelum konflik terjadi, sektor pariwisata ini cukup maju, akan tetapi sejak mencetusnya konflik terlihat sekali baik secara nyata maupun tidak bahwa objekobjek daya tarik wisata budaya kurang perhatian dan terawat.

Penentuan informan dilakukan secara purposive, yaitu yang mempunyai pengetahuan tentang pariwisata budaya dan kondisi wisata sebelum atau pasca konflik. Informan yang dipilih yaitu pihak pemerintah seperti Dinas Porabudpar Kabupaten Sambas, pihak Kecamatan Sambas kemudian pihak swasta yang terkait mengelola pariwisata setempat, dan tokoh masyarakat yang dapat menjelaskan kondisi pariwisata budaya di Sambas pasca konflik etnis.

Analisis data dalam penelitian kualitatif, dilakukan pada saat pengumpulan data berlangsung dan setelah selesai pengumpulan data dalam periode tertentu. Pada saat wawancara, peneliti sudah melakukan analisis terhadap jawaban yang diwawancarai. Bila jawaban yang telah dianalisis terasa belum memuaskan maka peneliti akan melanjutkan pertanyaan lagi sampai tahap tertentu diperoleh data yang dianggap kredibel.

Miles dan Huberman (1984) mengemukakan aktivitas analisis kualitatif dilakukan dengan interaktif yang dilakukan secara terus menerus sampai tuntas sehingga datanya sudah jenuh. Aktivitas tersebut terdiri atas tiga alur kegiatan yang terjadi bersamaan yaitu reduksi data, penyajian data, dan penarikan simpulan (Sugiyono : 2009).

\section{HASIL DAN PEMBAHASAN}

\subsection{Destinasi Wisata Budaya Kecamatan Sambas}

\begin{tabular}{|l|l|l|}
\hline No & Nama DTW & Jenis DTW \\
\hline 1. & Komplek Kesultanan Sambas & Budaya \\
\hline 2. & $\begin{array}{l}\text { Tempat Tinggal Siradj Sood (Dato' Kaya Lela } \\
\text { Mahkota) }\end{array}$ & Budaya \\
\hline 3. & P erkampungan Tenun Songket & Budaya \\
\hline 4. & $\begin{array}{l}\text { Rumah Tinggal Maharaja Imam Haji } \\
\text { Muhammad Basiuni Imran }\end{array}$ & Budaya \\
\hline 5. & Makam Syeh Abdul Jalil Al Fatani & Budaya \\
\hline 6. & Museum Negeri Sambas & Budaya \\
\hline 7. & Tari-Tarian Tradisional Sambas & Budaya \\
\hline
\end{tabular}

\section{a. Komplek Kesultanan Sambas}

Keraton Alwatzikhoebillah Sambas merupakan daya tarik wisata sejarah yang berbasis masyarakat lokal berlokasi di Desa Dalam Kaum Kecamatan Sambas Kabupaten Sambas Provinsi Kalimantan Barat. Keraton Alwatzikhoebillah Sambas terletak di tepi Muara Ulakan simpang tiga pertemuan sungai Sambas Kecil, Subah, Teberau.

Komplek Kesultanan Sambas terletak di daerah pertemuan sungai pada bidang tanah yang berukuran sekitar 16.781 meter persegi 
membujur arah barat-timur. Pada bidang tanah ini terdapat beberapa buah bangunan, yaitu dermaga tempat perahu/kapal sultan bersandar, dua buah gerbang, dua buah paseban, Kantor tempat sultan bekerja, bangunan inti keraton (balairung), dapur, dan masjid sultan. Bangunan keraton menghadap ke arah barat ke arah sungai Sambas. Ke arah utara dari dermaga terdapat Sungau Sambas Kecil, dan ke arah selatan terdapat Sungai Teberau. Di sekeliling tanah keraton merupakan daerah rawa-rawa dan mengelompok di beberapa tempat terdapat makam keluarga sultan.

Bangunan keraton yang lama dibangun oleh Sultan Bima pada tahun 1632 (sekarang telah dihancurkan), sedangkan keraton yang masih berdiri sekarang dibangun pada tahun 1933. Sebagai sebuah keraton di tepian sungai, di mana sarana transportasinya perahu/ kapal, tentunya di tepian sungai dibangun dermaga tempat perahu/kapal sultan bersandar. Dermaga yang terletak di depan keraton dikenal dengan Nama jembatan Seteher. Jembatan ini menjorok ke tengah sungai. Dari dermaga ini ada jalan yang menuju keraton dan melewati gerbang masuk.

Gerbang masuk yang menuju halaman keraton dibuat bertingkat dua dengan denahnya berbentuk segi delapan dan luasnya 76 meter persegi. Bagian bawah digunakan untuk tempat penjaga dan tempat beristirahat bagi rakyat yang hendak menghadap sultan, dan bagian atas digunakan untuk tempat mengatur penjagaan. Selain itu, bagian atas pada saat-saat tertentu digunakan sebagai tempat untuk menabuh gamelan agar rakyat seluruh Kota dapat mendengar kalau ada keramaian di keraton.

Setelah melalui pintu gerbang yang bersegi delapan, di tengah halaman keraton dapat dilihat tiang bendera yang disangga oleh empat batang tiang. Tiang bendera ini melambangkan sultan, dan tiang penyangganya melambangkan empat pembantu sultan yang disebut wazir. Di bagian bawah tiang bendera terdapat dua pucuk meriam, dan salah satu di antaranya bernama Si Gantar Alam. Sebelum memasuki keraton, dari halaman yang ada tiang benderanya, kita harus melalui lagi sebuah gerbang. Gerbang masuk ini juga terdiri dari dua lantai, tetapi bentuk denahnya empat persegi panjang. Lantai bawah tempat para penjaga yang bertugas selama 24 jam, sedangkan lantai atas dipakai untuk keluarga sultan beristirahat sambil menyaksikan aktivitas kehidupan rakyatnya sehari-hari. Setelah melalui gerbang kedua dan pagar halaman inti, sampailah pada bangunan keraton.

Di bagian dalam bangunan tempat Sultan dan pembantunya bekerja, tersimpan beberapa benda pusaka kesultanan, di antaranya singgasana kesultanan, pedang pelantikan Sultan, gong, tombak, payung kuning yang merupakan lambang kesultanan, dan meriam lele. Meriam lele yang jumlahnya tujuh buah hingga sekarang masih dianggap barang keramat dan sering diziarahi penduduk. Masing-masing meriam yang berukuran kesil ini mempunyai nama, yaitu Raden Mas, Raden Samber, Ratu Kilat, Ratu Pajajaran, Ratu Putri, Raden Pajang, dan Panglima Guntur.

Bangunan utama keraton berukuran 11, 50 $x$ 22, 60 meter. Terdiri atas tujuh ruangan, yaitu balairung terletak di bagian depan, kamar tidur sultan, kamar tidur istri sultan, kamar tidur anakanak sultan, ruang keluarga, ruang makan, dan ruang khusus menjahit. Di bagian atas ambang pintu yang menghubungkan balairung dan ruang keluarga, terdapat lambang Kesultanan Sambas dengan tulisan "Sultan van Sambas" dan angkatahun 15 Juli 1933. Angka tahun ini merupakan tanggal peresmian bangunan keraton. Di bagian dalam bangunan ini, pada kamar tidur Sultan tersimpan barang-barang khazanah Kesultanan Sambas, di antaranya tempat peraduan sultan, pakaian kebesaran, payung kesultanan, pedang, getar, puan, dan meja tulis Sultan. Pada bagian dinding terpampang gambar-gambar keluarga Sultan yang pernah memerintah Sambas. 


\section{b. Tempat Tinggal Siradj Sood (Dato' Kaya Lela Mahkota)}

Rumah Siradj Sood (Dato' Kaya) merupakan salah satu tinggalan sejarah di Kecamatan Sambas yang lokasinya terletak di Jalan Ahmad Sood Dusun Tumok, Desa Tumok Manggis, Kecamatan Sambas. Bangunan tersebut awal mulanya merupakan rumah salah satu pejuang Sambas yang bernama H. Siradj Sood atau yang lebih dikenal dengan julukan Datuk Kaya (Tok Kaye). Rumah tinggal ini telah berusia sekitar 350 Tahun. Hingga tahun 2014 tempat bersejarah ini pernah dijadikan sebagai Museum Negeri Perjuangan Sambas. Akan tetapi, kini Rumah Tua ini telah beralih fungsi yang dikelola oleh keluarga dari Dato' Kaya sendiri. Rumah ini sekarang hanya dijadikan tempat pertemuan keluarga besar. Sesekali rumah ini menjadi tempat pertemuan kegiatan PKK maupun kegiatan keagamaan seperti BKMT Kecamatan.

\section{c. Perkampungan Tenun Songket}

Hampir setiap rumah warga di Desa Sumber Harapan ini memiliki alat tenun, ini bukan merupakan hal baru, karena kerajinan tenun Lunggi (Kain Tenun Khas Sambas) sudah ada sejak lama dan diwariskan secara turun-temurun dari generasi ke generasi sampailah sekarang ini. Hampir seluruh warga desa Sumber Harapan (Semberang) memiliki keterampilan menenun, bahkan anak-anak yang masih duduk dibangku pendidikan sekolah dasar (SD) pun sudah diajarkan orang tuanya untuk menenun, sampai menginjak bangku SMP ada SMA, sudah ada yang mahir untuk membuat kain tenun Lunggi sendiri.

Kerajinan tenun sendiri merupakan pekerjaan sambilan ibu rumah tangga di Desa Semberang. Mereka menenun disela-sela waktu kosong mereka setelah mengerjakan pekerjaan rumah tangga maupun bertani. Meskipun hanya sebagai pekerjaan sampingan, hasil dari kerajinan tenun mereka ini merupakan bisnis yang cukup menjanjikan karena harga dari hasil kerajinan tenun ini dihargai dengan harga yang tinggi. Hasil kerajinan dari desa Semberang ini sendiri pada awalnya hanya dijual, dipesan dan dipakai untuk kalangan masyarakat melayu sambas dan pada acara tertentu saja.

Sekarang sesuai dengan perkembangan jaman, kain tenun songket hasil kerajinan ini sudah berkembang dan pemasarannya semakin luas. Sehingga sudah dipasarkan ketingkat nasional bahkan internasional dengan harga yang tinggi. Ini mengindikasi bahwa produk kerajinan Tenun dari Kalimantan Barat mampu bersaing dengan Produk kerajinan tenun dari seluruh Nusantara, dan ini merupakan kebanggan tersendiri bagi warga Kalimantan Barat, khususnya masyarakat Desa Semberang, Kabupaten Sambas.

\section{d. Rumah Tinggal Maharaja Imam Haji Muhammad Basuni Imran}

Salah satu peninggalan bersejarah lainya yang ada di sambas dan menjadi objek wisata adalah Museum Tamadun Islam Negeri Sambas. Bangunan ini berada dalam kota sambas di kampung Dagang Timur. Lokasinya berada tepat menghadap sungai khususnya dipinggiran sungai teberau. Museum ini pada awalnya adalah tempat tinggal seorang ulama besar Islam asal Sambas yaitu syaikh Muhammad Basuni Imran. Beliau terkenal sebagai seorang tokoh yang mempunyai peran besar dalam memajukan pendidikan khusunya pendidikan agama di Sambas.

Secara umum museum ini masih asli arsitekturnya. Namun karena perjalanan masa, beberapa bagian dari keseluruhan bangunan ini sudah ada yang diganti dan hilangkan. Bagian yang diganti itu adalah atap bangunan yang awalnya menggunakan bahan kayu yaitu atap sirap. Karena sudah rapuh dan rusak sementara untuk mencari bahan pengganti yang Sama sudah sulit bahkan tidak ada, maka digantilah dengan bahan metal.

Kemudian Desa Lumbang sekitar 1180-an H/1760-an M, penduduk Kuala Mempawah, 
Tanjung Mempawah dan kampung-kampung sekitarnya terkejut kerana didatangi oleh sekitar 40 perahu yang besar. Setelah dua orang ulama, Sheikh Ali bin Faqih al-Fathani dan Sheikh Abdul Jalil al-Fathani naik ke darat untuk menghadap Upu Daeng Menambon, iaitu Raja Mempawah pada masa itu, barulah diketahui oleh penduduk bahwa perahu-perahu itu datang dari negeri Fathani Darus Salam. Kedua-dua ulama itu mendapat kedudukan dan dihormati oleh masyarakat kerana pengetahuan luas mereka dalam keislaman.

Sheikh Abdul Jalil al-Fathani meneruskan penyebaran Islam ke Sambas, setelah meninggal dunia oleh penduduk Lumbang beliau dimakamkan di Lumbang, Sambas. Pada akhirnya di Lumbang ini, khususnya di Sambas, Syeikh Abdul Jalil al-Fathani lebih dikenali dengan sebutan Keramat Lumbang kerana beliau dikeramatkan orang adalah sebagai lambang ketinggian ilmunya hingga kepada ilmu hakikat dan makrifat. Sampai sekarang makan ini banyak dikunjungi oleh masyarakat untuk berziarah.

\section{e. Museum Sambas}

Museum Sambas merupakan daya ratik wisata yang banyak dikunjungi. Museum Sambas saat ini berlokasi dekat dengan pendopo bupati Kampung Lorong Sambas yang sebelumnya beradi di rumah Dato' Kaya. Pendirian Museum Negeri Perjuangan Sambas berkat adanya gagasan dari tokoh masyarakat yang sadar budaya dan tokoh-tokoh budaya Sambas yang tergabung dalam Dinas Pemuda, Olahraga, Budaya Dan Pariwisata (DISPORABUDPAR). Sesuai dengan namanya, Museum Negeri Perjuangan Sambas merupakan sebuah museum yang mengoleksi benda-benda yang pernah digunakan oleh masyarakat Sambas dalam memperjuangkan Kemerdekaan Republik Indonesia khususnya di daerah Sambas. Bendabenda yang dipergunakan merupakan bendabenda yang masih sangat sederhana diantaranya beberapa jenis tombak, pedang, dan Keris.
Selain berupa benda-benda yang digunakan untuk perjuangan, Museum Negeri Perjuangan Sambas juga memuat berbagai macam koleksi yang digunakan dalam kehidupan sehari-hari masyarakat Sambas. Ianya berupa beragam jenis Tempayan yang sering digunakan sebagai wadah air, beraneka jenis Kain Tenun Sambas yang memiliki ciri dan karakter khas tiap-tiap daerah di Sambas dan sering digunakan dalam acara-acara penting (resmi).

Berbagai macam koleksi yang terdapat di Museum Negeri Perjuangan Sambas sebagian besar merupakan benda-benda milik pribadi $\mathrm{H}$. Siradj Sood. Selain itu terdapat benda-benda lain yang merupakan hasil temuan, hibah dan titipan dari individu ataupun kelompok orang tertentu yang peduli dengan keberadaan museum dalam rangka menambah koleksi yang sudah ada.

\section{f. Sanggar Tari Rama}

Sanggar Tari Rama merupakan Sanggar tari yang masih aktif di Kecamatan Sambas. Sanggar Tari Rama berupaya melestarikan tarian-tarian tradisional khas Sambas seperti Tanda' Sambas, Zapin dsb. Pendiri utama sanggar tari ini adalah ibu Iklima yang juga menguasai tarian Sambas. Akan tetapi seiring berjalannya waktu sanggar tari Rama ini beralih kepengerusan yang dikelola oleh ibu Maya Tari. Sanggar Tari rama ini juga merupakan atraksi yang dijadikan pariwisata. Melalui sanggar tari ini pariwisata Sambas dapat di promosikan di berbagai daerah baik dalam maupun luar negeri.

\subsection{Upaya Pemulihan Pariwisata Budaya Pasca Konflik}

\section{a. Upaya Pemulihan Pariwisata Budaya dilihat dari aspek Infrastruktur}

Tabel dibawah ini memperlihatkan adanya upaya-upaya secara fisik yang dilakukan baik oleh pihak pemerintah maupun swasta dalam upaya pemulihan pariwisata budaya yang ada di Sambas. 
Tabel 1. Upaya Pemulihan Pariwisata Budaya Pasca Konflik

\begin{tabular}{|c|c|c|c|c|c|}
\hline No & $\begin{array}{l}\text { Nama Objek } \\
\text { Wisata Budaya }\end{array}$ & $<$ Pra Konflik & > Pasca Konflik tahun 1999 & $\begin{array}{l}\text { Tahun dan } \\
\text { bentuk } \\
\text { renovasi }\end{array}$ & $\begin{array}{l}\text { Bantuan } \\
\text { Dari }\end{array}$ \\
\hline 1. & $\begin{array}{l}\text { Komplek } \\
\text { Kesultanan } \\
\text { Sambas }\end{array}$ & Cagar Budaya & $\begin{array}{l}\text { - Halaman di Semen } \\
\text { - atap dicat } \\
\text { - gedung dicat } \\
\text { - peranginan/ steher dibuat baru } \\
\text { - jalan diperbaiki } \\
\text { - tempat tidur sultan dipermak } \\
\text { - Pelaminan Pengantin }\end{array}$ & 2007 & $\mathrm{APBD}$ \\
\hline 2. & $\begin{array}{l}\text { Makam } \\
\text { Kesultanan } \\
\text { Sambas }\end{array}$ & - Hanya nisan & $\begin{array}{l}\text { - pembangunan makam Muhrum Jama' } \\
\text { - penataan makam winata kusuma } \\
\text { - Umar Kamaludin } \\
\text { - sultan Usman Kamaludin } \\
\text { - Umar kamaludin } 3\end{array}$ & $\begin{array}{l}2008,2009, \\
2010 \text { dan } \\
2011\end{array}$ & APBD \\
\hline 3. & $\begin{array}{l}\text { Makam Al- } \\
\text { Fatani }\end{array}$ & $\begin{array}{l}\text { - Tidak adanya jembatan } \\
\text { menghubungkan } \\
\text {-menggunakan sampan }\end{array}$ & $\begin{array}{l}\text { - akses jalan baik } \\
\text { - adanya jembatan }\end{array}$ & 2008 & APBD \\
\hline 3. & Seni Budaya & $\begin{array}{l}\text { - alat dan baju lama mulai } \\
\text { rusak }\end{array}$ & $\begin{array}{l}\text { - Pengadaan seragam japin } \\
\text { - tahar untuk zikir } \\
\text { - cetak buku-buku cerita rakyat } \\
\text { - acara pentas seni dan budaya Sambas } \\
\text { - bantuan baju seragam nari } \\
\text { - tahar }\end{array}$ & 2008 & $\begin{array}{l}\text { APBD/ CSR } \\
\text { (perkebunan } \\
\text { Sawit) }\end{array}$ \\
\hline 4. & $\begin{array}{l}\text { Kampung } \\
\text { Tenun }\end{array}$ & $\begin{array}{l}\text { - Akses jalan Kurang Baik } \\
\text { - Lewat Transportasi } \\
\text { Sungai }\end{array}$ & $\begin{array}{l}\text { Galeri } \\
\text { - Pelatihan- pelatihan Tenun } \\
\text { - Bantuan Alat-alat tenun } \\
\text { - akses jalan sangat baik }\end{array}$ & 2013 & $\begin{array}{l}\text { Garuda } \\
\text { Indonesia } \\
\text { Dompet Umat }\end{array}$ \\
\hline 6. & $\begin{array}{l}\text { Rumah Dato' } \\
\text { Kaya }\end{array}$ & - Museum Perjuangan & $\begin{array}{l}\text { - Dari Museum menjadi Rumah } \\
\text { pertemuan keluarga } \\
\text { - Tempat pertemuan sosial keagamaan } \\
\text { (Arisan/ BKMT) }\end{array}$ & Sekarang & $\begin{array}{l}\text { - Pihak } \\
\text { keluarga }\end{array}$ \\
\hline 7. & Museum & $\begin{array}{l}\text { - Di rumah Dato' Kaya } \\
\text { - Barang tidak dilindingi dan } \\
\text { Dapat di sentuh langsung }\end{array}$ & $\begin{array}{l}\text { - Dipindah dari rumah datok kaya ke } \\
\text { pendopo } \\
\text { - Ada AC } \\
\text { Lemari Kaca }\end{array}$ & Tahun 2014 & $\begin{array}{l}\text { - bantuan dari } \\
\text { Pusat }\end{array}$ \\
\hline
\end{tabular}

Komplek kesultanan Sambas sebelum tahun 1999 atau pada saat Sambas masih menjadi Kecamatan hanya sebatas cagar Budaya akan tetapi, belum banyak perubahan infrastrukture. Namun demikian wisata Istana Sambas sangat banyak dikunjungi wisatawan lokal. Kemudian pada tahun 2007 setelah mekarnya Kabupaten Sambas, ada beberapa penambahan infrastruktur dari APBD Halaman di Semen, atap dicat, gedung dicat, peranginan/ steher dibuat baru, jalan diperbaiki, tempat tidur sultan dipermak, Pelaminan Pengantin. Sebagaimana diketahui 
bahwa komplek kesultanan ini merupakan cagar budaya sehingga perubahan pembangunan tidak serta merta dapat dilakukan begitu saja namun mengikuti prosedur benda cagar budaya.

Makam Raja-raja Sambas yang menjadi bagian dari sejarah sebelum tahun 1999 tidak mendapatkan perhatian lebih. Selanjutnya pada tahun 2008, 2009, 2010 dan 2011 mendapatkan perhatian dan pemerintah untuk pemugaran. Adapaun makam yang mendapat perhatian yakni pembangunan makam Muhrum Jama', penataan makam winata kusuma, Umar Kamaludin, sultan Usman Kamaludin dan makan Umar kamaludin 3. Termasuklah makan yang memiliki sejarah yakni; makam Abdul Jalil Alfatani yang sebelum tahun 1999 jika hendak berziarah ke makam ini nenggunakan Sampan karena berada di seberang sungai Lumbang. Akan tetapi sejak tahun 2008 telah terdapat jembatan penghubung dan akses jalan yang baik yang dapat dilalui dengan sepeda motor.

Seni Budaya di Sambas paling banyak berkembang terutama sanggar-sanggar tari, sebelum tahun 1999 baju-baju tari, dan alatalat tari sudah cukup tua dan mulai mengalami kerusakan. Pada tahun 2008 ada beberapa bantuan baik dana APBD maupun CSR perusahaan Sawit yang ada di wilayah Kab. Sambas, seperti bantuan Pengadaan seragam japing, tahar untuk zikir, cetak buku-buku cerita rakyat, acara pentas seni dan budaya Sambas, bantuan baju seragam nari serta tahar sebagai alat musik.

Sebelum pemekaran Sambas, Kampung tenun memang telah ada dan banyak penduduk yang bertenun secara mandiri, dan belum ada bantuan tenun serta pendampingan pelatihan dan pemasaran. Akan tetapi setelah tahun 1999 bantuan untu masyarakat Desa Sumber Harapan dibina langsung oleh Garuda Indonesia (GI) dan Dompet Umat. Bantuan tersebut berupa Galeri Tenun, Bantuan Alat-Alat tenun dan pelatihanpelatihan tenun. Hingga saat ini kampung tenun sambas juga telah memiliki akses jalan yang sangat baik dapat dilalui dengan transportasi darat dan transportasi sungai.

Rumah Dato' Kaya sebelum tahun 1999 rumah datok kaya di ambil alih oleh Pemda Sambas sebagai museum perjuangan dikatakan sebagai museum perjuangan karena banyak memiliki benda sejarah ala-alat perjuangan seperti keris, tombak, meriam dsb. sejak tahun 2014 Museum ini telah di kembalikan pada pihak keluarga dato' kaya dan sekarang hanya di jadikan tempat pertemuan keluarga, kegiatan, kemasyarakatan, BKMT dan ibu PKK. Saat ini pihak keluargalah yang berperan dalam pembenahan. Selanjutnya Museum Negeri Sambas, barang-barang pada museum ini adalah barang yang dipindahkan dari Museum Perjuangan yang saat ini berada di daerah Kampung Lorong Sambas dengan mendapat bantuan dari pusat dengan fasilitas yang cukup baik dari tahun sebelumnya seperti adanya etalase, AC dan gedung yang nyaman walaupun masih terlalu sempit.

Demikianlah perkembangan infrastruktur wisata budaya yang ada di Kecamatan Sambas, walaupun menurut keterangan bahwa kunjukan dan kemajuan wisata Sambas lebih baik sebelum sambas mengalami pemekaran. Hal ini dapat dikarenakan pertumbuhan pesat wisata yang ada di Kota Singkawang.

\section{b. Upaya Pemulihan Pariwisata Budaya Melihat Aspek Kemanan}

Kondisi keamanan pada Daya Tarik Wisata Budaya sangat diperlukan terutama bagi wisatawan yang hendak berkunjung ke Kabupaten Sambas. Mengingat Sambas pernah terjadi konflik etnis pada tahun 1999, yang hingga saat ini salah satu suku bangsa tertentu tidak boleh untuk tinggal di wilayah ini. Kehawatiran bagi wisatawan masih ada terutama oleh etnis Madura. Pemerintah sebagai orang birokrasi mengatakan bahwa tidak ada masalah untuk berkunjung ke Kabupaten Sambas jika hanya sekedar berwisata. Hal ini sesuai dengan defenisi pariwisata yang 
hanya bertujuan berekreasi dalam waktu yang sementara bukan untuk tinggal dan menetap.

Tidak hanya pemerintah sebagian besar masyarakat Kecamatan Sambas yang mengatakan secara pribadijuga mengungkapkan hal yang Sama tidak berkeberatan bagi etnis Madura ataupun seluruh bangsa manapun untuk datang ke Kabupaten Sambas jika hanya bertujuan untuk menikmati keindahan budaya dan sejarah Sambas. Pemerintah Kabupaten Sambas juga terus menjaga keamanan dan ketertiban ada baik pada tingkat RT, RW, Dusun, Desa dan Kecamatan dengan menghimbau kepada seluruh warga masyarakat untuk dapat berpartisipasi dalam menjaga kemanan melalui SISKAMLING.

\section{c. Upaya Pemulihan Pariwisata Melalui Aspek Pengembangan Sumber Daya Manusia.}

Peningkatan Sumber Daya Manusia sangat berperan penting dalam kemajuan pariwisata keduapannya. Demikian halnya di Kabapten Sambas, pemerintah juga melakukan berbagai pelatihan terkait pariwisata. Khusus untuk Desa Wisata Tenun, yang mengedepankan budaya, ini lebih banyak melaksanakan penikatan dengan pelatihan tenun agar lebih bersaing dengan daerah lain, mulai dari pelatihan motif-motif terbaru, produksi yang cepat hingga pemasaran tenun dan pemasaran pariwisata. Sedangkan untuk Sanggar Tari Rama juga melakukan peningkatan SDM untuk memperkenalkan budaya Sambas melalui pelatihan bahasa Inggris bagi anggotanya.

\section{d. Upaya Pemulihan Pariwisata Melalui Promosi Pariwisata}

Promosi merupakan hal penting dalam pengenalan pariwisata, demikian juga pemerintah Kabupaten Sambas yang telah mencoba untuk melakukan promosi kembali setelah melakukan pemekaran wilayah dan pernah terjadi konflik pada tahun 1999. Adapun promosi yang dilakukan di Kabupaten sambas yakni pemerintah mencanangkan program untuk melakukan pameran baik di tingkat lokal maupun Nasional. Pemerintah juga membuat brosur-brosur, liflet dan video lagu-lagu daerah menampilkan tempat-tempat wisata budaya yang ada di Kecamatan Sambas. Selain itu masyarakat saat sambas saat ini sedang gencar membuat film-film daerah yang juga mengambil wisata budaya menjadi tempat syuting. Selain itu, sebagai Desa Wisata Tenun juga melakukan promosi wisata dengan menggelar pembuatan tenun terpanjang hingga mendapat rekor MURI ini merupakan bentuk promosi wisata yang telah dilaksanakan dalam upaya pemulihan pariwisata budaya yang ada di Kecamatan Sambas. Kemudian promosi berbentuk lisan dari mulut ke mulut antar teman, dan keluarga juga sangat efektif untuk meningkatkan kunjungan wisatawan.

Adapun Hambatan yang paling mendasar dalam upaya pemulihan wisata budaya di Kecamatan Sambas yakni kurangnya integrasi antar stakeholder dalam membangun pariwisata budaya di Kecamatan Sambas. Selain itu pernah terjadi disharmonis antar etnis yang hingga kini belum juga terintegrasi secara baik. Walaupun sebagaian besar masyarakat Sambas sudah menerima semua suku bangsa apapun untuk berwisata di Sambas.

Adapun Hambatan yang paling mendasar dalam upaya pemulihan wisata budaya di Kecamatan Sambas yakni kurangnya integrasi antar stakeholder dalam membangun pariwisata budaya di Kecamatan Sambas. Selain itu pernah terjadi disharmonis antar etnis yang hingga kini belum juga terintegrasi secara baik. Walaupun sebagaian besar masyarakat Sambas sudah menerima semua suku bangsa apapun untuk berwisata di Sambas.

\section{KESIMPULAN}

Berdasarkan hasil pembahasan dan data lapangan yang telah diperoleh penelitian ini 
ada beberapa rekomendasi yang dihasilkan dalam upaya pemulihan pariwisata budaya di Kecamatan Sambas, yakni dapat mengembangan wisata budayanya dengan membuka diri dan siap menerima setiap tamu yang datang dan hendak berwisata di Kab. Sambas, sebagian besar masyarakat secara personal juga telah menerima etnis Madura yang hanya untuk berwisata di Kecamatan Sambas. Adapun upaya yang dapat dilakukan berbagai pihak yaitu melalui upaya peningkatan infrastruktur, melakukan peningkatan SDM dengan melakukan pelatihan, melakukan promosi wisata seperti mengikuti berbagai pameran baik nasional maupun internasional dan memperoleh rekor MURI . Hambatan dalam melakukan upaya tersebut yakni kurangnya integrasi antar stakeholder dalam membangun pariwisata budaya di Kecamatan Sambas. Selain itu pernah terjadi disharmonis antar etnis yang hingga kini belum juga terintegrasi secara baik walaupun masyarakat Sambas dan pemerintah telah menerima secara pribadi.

\section{Daftar Pustaka}

Ardika, I Gede.2001, Paradigama Baru Pariwisata Kerakyatan Berkelanjutan, Denpasar: Makalah 3 rd International Symposium of The Journal antropolgy Indonesia.

Asmara, Husna. 2001 Melayu dan Budayanya" Sebuah Analisis untuk Mengatasi Eskalasi Konflik Komunal". Disampaikan Pada
Musyawarah Anak Bangsa di Bumi Khatulistiwa di Pontianak, 24-25 April.

Maleong, Lexy, J.2010. Metode Penelitian Kualitatif. Bandung: PT Remaja Rosdakarya.

Marisa, 2013. Upaya Pemerintah Srilanka Dalam Mengembangkan Pariwisata Pasca Konflik.e Journal. Ilmu Pemerintahan Internasional. 1(4): 1055-1064 Fisip Unmul.

Musa. J. B Suta Purwana dan P. Johansen. 2000 Kerusuhan Sambas Tahun 1999. Balai Kajian Sejarah dan Nilai Tradisional Pontianak. (Laporan Penelitian Tidak Diterbitkan).

Nurchalis, 2011. Peran Serta Pemerintah Dan Masyarakat Dalam Upaya Pelestarian Keraton Alwatzikhoebillah Sebagai Daya Tarik Wisata Sejarah Di Sambas Kalimantan Barat (Tesis Kajian Pariwisata Program Pascasarjana Universitas Udayana).Bali: Udayana Press.

Paloma, Margaret M. 2004. Sosiologi Kontemporer. Jakarta: CV Raja Wali.

Pitana, I.G dan Gayatri, P.G, 2005. Sosiologi Pariwisata. Yogyakarta: Andi.

Setiadi, 2006. Kultur Konflik dan Kekerasan Etnis-Fenomea Etno Migrasi Etnis Madura di Kalimantan Barat dalam Esei-Esei Antropologi-Teori, Heddy Shri Ahimsa Putra (Ed) Metodologi dan Etnografi. Yogyakarta: KEPEL press.

Sugiyono, 2009. Memahami Penelitian Kualitatif. Bandung: CV Alfabe 